\title{
EVALUATION OF CARNAUBA PROGENIES AND ESTIMATES OF GENETIC PARAMETERS IN THE JUVENILE PHASE ${ }^{1}$
}

\author{
LUNARA GRAZIELLY COSTA DA SILVA ${ }^{2 *}$, JEFFERSON FRANCISCO LIMA MOREIRA ${ }^{2}$, HERICLES BRUNO \\ BEZERRA HOLANDA², EMANUEL LUCAS BEZERRA ROCHA ${ }^{2}$, POLIANA COQUEIRO DIAS ${ }^{2}$
}

\begin{abstract}
Carnauba (Copernicia prunifera) is a forest species with multiple uses, and is of great economic and social importance for several communities involved in extractive agriculture in northeastern Brazil. However, there are few studies on genetic variability in this species. Thus, this work aimed to produce information about the genetic characterization of $C$. prunifera seeds and seedlings, using provenance and progeny evaluations. A progeny test was performed in a plant nursery, using seeds of 36 matrices sampled in the municipalities of Mossoró and Apodi (Rio Grande do Norte State), and Russas and Icapuí (Ceará State). Three groups were derived according to the spatial distance between the collected matrices. Biometric analyses of the seeds were performed, adopting a completely randomized experimental design, with four replicates of 25 seeds in each analysis. A randomized block design (five replicates and five plants per plot) was used at the seedling production phase. The data evaluated included the emergence speed index, emergence percentage, leaf size, leaf base diameter, and survival (at 30, 60, and 90 days after sowing). The restricted maximum likelihood method was used in the statistical analysis, with the aid of SELEGEN software. In order to evaluate genetic variability in the $C$. prunifera population samples, it was verified that the juvenile characters presented a moderate genetic control. The three groups of spatially delimited matrices presented no significant genetic differences. This information may assist in the development of forestry practice for this species.
\end{abstract}

Keywords: Forestry. Genetic conservation. Genetic enhancement.

\section{AVALIAÇÃo de PROGÊNIES de CARNAÚbA NA FASE JUVENIL E ESTIMATIVAS DE PARÂMETROS GENÉTICOS}

\begin{abstract}
RESUMO - A carnaubeira (Copernicia prunifera) é uma espécie florestal que apresenta múltiplos usos e de grande importância econômica e social para várias famílias extrativistas no Nordeste brasileiro. Entretanto, são escassos os estudos a respeito da variabilidade genética da espécie. Assim, este trabalho buscou gerar informações em relação à caracterização genética de sementes e mudas de Copernicia prunifera, avaliando procedências e progênies. Instalou-se um teste de progênies, em viveiro, a partir de sementes de 36 matrizes amostradas nos Municípios de Mossoró e Apodi, no Estado do Rio Grande do Norte; e em Russas e Icapuí, no Estado do Ceará. A partir da distância espacial entre as matrizes coletadas foram formados três grupos. Foram realizadas análises biométricas das sementes, adotando o delineamento experimental inteiramente casualizado, com quatro repetições de 25 sementes para cada análise. O delineamento em blocos casualizados com cinco repetições e cinco plantas por parcela foi empregado na fase de produção de mudas. Os dados avaliados incluíram: índice de velocidade de emergência, porcentagem de emergência, tamanho da folha, diâmetro da base da folha e sobrevivência (aos 30,60 e 90 dias após a semeadura). A metodologia de máxima verossimilhança restrita foi utilizada para a análise estatística, com o auxílio do software SELEGEN. Verificouse que os caracteres juvenis apresentam controle genético médio, podendo ser utilizados para avaliação da variabilidade genética de amostras de populações da espécie. Os três grupos de matrizes delimitados espacialmente não apresentam diferenças genéticas significativas. Essas informações podem auxiliar no desenvolvimento da silvicultura da espécie.
\end{abstract}

Palavras-chave: Silvicultura. Conservação genética. Melhoramento genético.

\footnotetext{
"Corresponding author

${ }^{1}$ Received for publication in 02/24/2017; accepted in 04/19/2018

${ }^{2}$ Department of Plant Sciences, Universidade Federal Rural do Semi-Árido, Mossoró, RN, Brazil; lunaragrazielly@msn.com - ORCID 0000-0001-9408-1814, jefferson.eng.florestal@outlook.com - ORCID: 0000-0003-4613-5704, hericlesbruno@hotmail.com - ORCID 0000-0001-9621-0093, elbrmanu@gmail.com - ORCID: 0000-0002-1265-0698, poliana.coqueiro@ufersa.edu.br - ORCID: 0000-00025744-2251.
} 


\section{INTRODUCTION}

Carnauba (Copernicia prunifera (Miller) $\mathrm{H}$. E. Moore) is a forest species with multiple uses. It is of great economic and social importance for several communities involved in extractive agriculture in northeastern Brazil, where it provides a source of income during the dry season, and because it can tolerate high salinity levels in the soil (ARRUDA; CALBO, 2004; ALVES; COELHO, 2006; HOLANDA et al., 2011; CARVALHO et al., 2015). The carnauba production chain consists of a set of economic activities that use the stipes, leaves, petioles, fibers, fruit, roots, and "carnauba wax" in particular, for various purposes (REIS et al., 2011; VIEIRA; OLIVEIRA; LOIOLA, 2016).

Despite the recognized importance and widespread use of $C$. prunifera in the semiarid region of northeastern Brazil, there remains a lack of information on various aspects of forestry, genetic conservation, and genetic improvement related to the species. Therefore, it is important to undertake research that expands the range of available technical and scientific information, and which provides genetic material for the species. This would be especially useful to small and medium producers, mainly owing to the possibility of multiple uses for the species, and the need to understand its adaptation to the soil and climate conditions of the region under study.

Copernicia prunifera is a forest species, native to Brazil and endemic in the northeast. It is present in the States of Piauí, Ceará, Rio Grande do Norte, Maranhão, Bahia, Alagoas, and Sergipe (ARRUDA; CALBO, 2004). Tree species with a wide occurrence and dispersed populations, such as C. prunifera, may have developed distinct characteristics over time, depending on their evolution in specific environmental conditions, that are restricted to the environment in which they occur. This factor may contribute to phenotypic variations within the same species, within a given population, and among different populations (BIERNASKI; HIGA; SILVA, 2012). Thus, these possible genetic variations within and between provenances should be considered when collecting seeds for the implementation of programs of genetic improvement, genetic conservation, and forestry production, to ensure that the genetic variability of the species is efficiently sampled (KAGEYAMA et al., 2003).

Given the diverse potential uses of $C$. prunifera, coupled with the scarcity of studies related to identifying superior genotypes for use in largescale plantations and on which knowledge about the genetic variability of the species can be based, generating information about its genetic diversity is important. Such information would be important to conservation of the species, as well as in selecting superior genotypes in the context of environmental and productive factors, and producing superior quality seedlings. It could also be used to support forestry applications focused on the recovery of degraded areas, and the establishment of plantations with a view to commercial production and urban afforestation.

Thus, this work aimed to generate information regarding the genetic characterization of $C$. prunifera seeds and seedlings, by evaluating provenances and progenies from four natural occurrences of the species in municipalities in the states of Rio Grande do Norte and Ceará. The ultimate purpose was to provide a basis for future collaboration in activities related to the genetic improvement, conservation, and production of superior quality seedlings of the species.

\section{MATERIAL AND METHODS}

The experiment was conducted at the Department of Plant Sciences, Universidade Federal Rural do Semi-Árido (UFERSA), Mossoró Campus $\left(5^{\circ} 11^{\prime} \mathrm{S}, 37^{\circ} 20^{\prime} \mathrm{W}\right.$; altitude, $\left.18 \mathrm{~m}\right)$. Rio Grande do Norte, Brazil. The seeds were collected from forest remnants in the municipalities of Mossoró and Apodi (State of Rio Grande do Norte), and Russas and Icapuí (State of Ceará). A total of 36 healthy $C$. prunifera palms were sampled in these areas. The choice of matrices was based on recommendations prescribed by Sebbenn (2006), which stipulate a minimum distance of $100 \mathrm{~m}$ between trees, in order to reduce the possibility of sampling related individuals. Sampling was carried out in different populations in such a way that it was possible to identify three groups of matrices by spatial distance (group one, 11 matrices; group two, 14 matrices; and group three, 11 matrices), in order to verify the existence of genetic differences between them. The spatial distribution of the sampled matrices, as well as the delimitation of the three groups, is shown in Figure 1.

The seeds were obtained from fruit collected at the maturation stage (stage evaluated by yellowgreen peel color), packed in plastic bags, and transported to the Post-Harvest Laboratory at the Department of Plant Sciences, UFERSA. In the laboratory, biometric analyses were conducted according to a completely randomized experimental design, in which four replicates of 25 seeds were adopted for each analysis. Seeds were selected at random for biometric evaluation of the characters of length, width, and thickness, using a digital caliper (accuracy, $0.01 \mathrm{~mm}$ ). Then, dormancy was overcome by immersing the seeds in water for 18 days until protrusion of the cotyledon petiole (OLIVEIRA; BOSCO, 2013; REIS et al., 2010), after which lots were selected for sowing. 


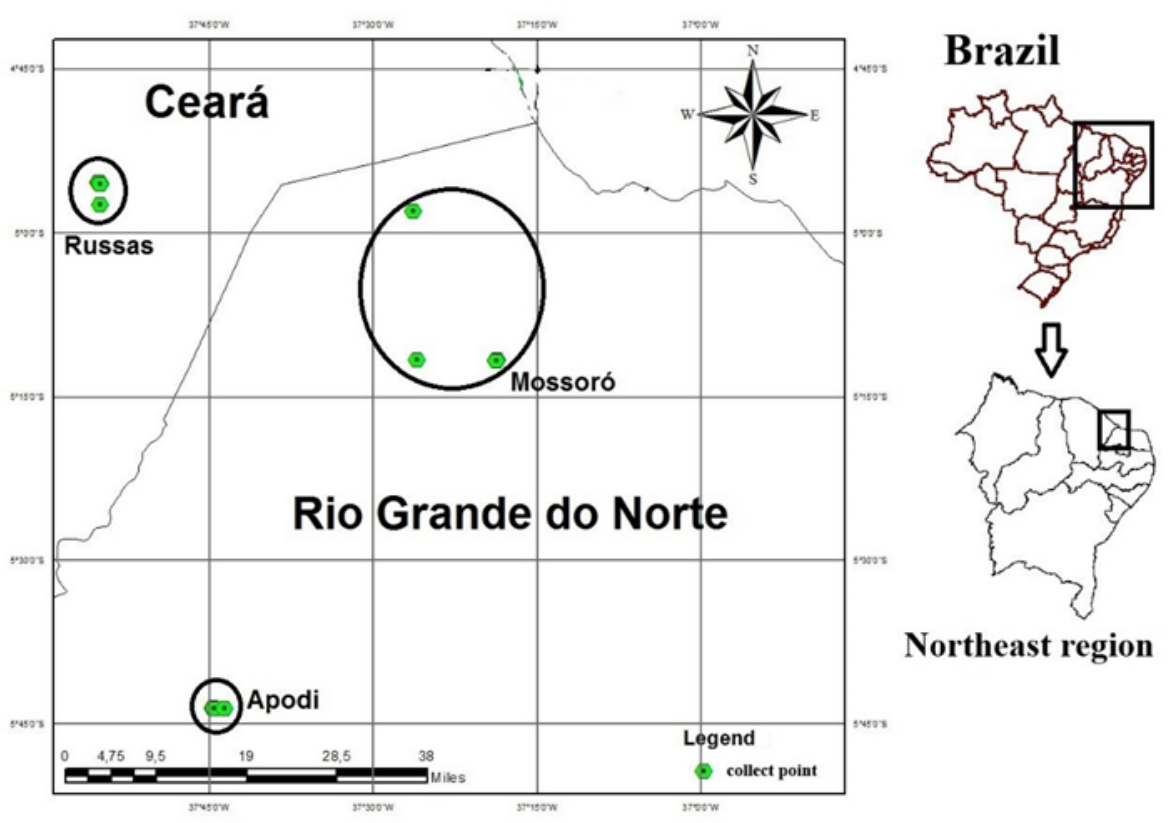

Figure 1. Map showing the study regions in the States of Rio Grande do Norte and Ceará, and the spatial distribution of the sampled matrices (36 matrices in the spatial groups) of $C$. prunifera. The distribution demonstrates three groups of spatially delimited matrices (highlighted with circles): group $1(\mathrm{G} 1)$ with 11 matrices, located in the municipality of Apodi; group 2 (G2) with 14 matrices, located in the municipalities of Icapuí and Mossoró; and group 3 (G3) with 11 matrices, located in the municipality of Apodi. Due to the scale, some points are superimposed.

Sowing of the progenies took the form of a progeny test, in order to evaluate the initial development of the material. The experiment was installed in the seedling production nursery at the Department of Plant Sciences, UFERSA. Sowing was undertaken in polyethylene pots (capacity, $2 \mathrm{~L}$ ), with three seeds per container, using a commercial substrate (Bioplant ${ }^{\circledR}$; main raw material: fiber and coconut powder; aggregates: Pinus bark, rice husk charcoal, vermiculite, and nutrients) mixed with sand washed at a ratio of 1:1. After sowing, the containers were taken to beds that provided $50 \%$ shading. The material was irrigated by spraying for $15 \mathrm{~min}$, twice per day; on days with high temperatures and low humidity, irrigation was performed three times per day. After seedling emergence, leaf size and leaf base diameter were measured every 15 days, until 90 days after emergence. The experimental design was a randomized block design with 36 treatments (progenies), five plants per plot, and five replicates.

Thirty days after seed sowing, the material was harvested, with the most vigorous seedling retained in each container. Data were collected for the emergence percentage, emergence speed index (IVE), leaf size measurements, and leaf base diameter (at 30, 60, and 90 days after sowing), and survival.

The IVE was calculated according to Maguire (1962): ${ }^{V E=\sum_{i}^{j} \frac{N i j}{D i j}}$ where IVE is the emergency speed index, $N i j$ is the number of seeds that emerged in the period, and $D i j$ is the day of the count.

The data analysis was performed using maximum likelihood methodology and the effect of the treatments, tested by analysis of deviance (ANADEV), using the software Systematic System and Computerized Genetic Selection (SELEGEN) (RESENDE, 2006).

The statistical model considered for estimating the existence of difference between the spatially delimited matrix groups was $y=X m+Z a$ $+W p+T b+e$, where $y$ is the data vector, $m$ the vector of the repetition effects (assumed as fixed) added to the general average, $a$ the vector of individual additive genetic effects (assumed to be random), $p$ the plot effects vector (assumed to be random), $b$ the vector of population (random) and $e$ the errors or residues (random). Capital letters represent the incidence matrices of these effects (RESENDE, 2006).

In order to estimate the genetic parameters of the entire sampled population, the statistical model used was $\mathrm{y}=X b+Z a+W c+\mathrm{e}$, where $\mathrm{y}$ is the data vector, $\mathrm{b}$ is the vector of repetition effects (assumed as fixed) to the vector of the individual additive genetic effects (assumed as random), the vector of the (random) plot effects, and the vector of (random) errors or residues. Capital letters represent the incidence matrices of these effects.

The coefficients of genetic variation between $(\mathrm{CVg})$ and within $(\mathrm{CVd})$ progenies were estimated using the mean squared hope derived from mean plot data, according to procedures described by Vencovsky and Barriga (1992).

Genetic diversity among progenies was estimated using a generalized Mahalanobis distance. 
The distances were then submitted to cluster analysis using the Tocher method (CRUZ; FERREIRA; PESSONI, 2011).

\section{RESULTS AND DISCUSSION}

Similar measurements were determined for seed width, thickness, and length in $C$. prunifera (Table 1). Thus, the biometric evaluations performed indicate that the carnauba seeds show homogeneity in relation to the biometric parameters evaluated, not differing among the seed collection sites.

Table 1. Mean biometric values of carnauba (Copernicia prunifera) seed width, thickness, and length, collected from Russas and Icapui municipalities in Ceará, and Apodi and Mossoró in Rio Grande do Norte.

\begin{tabular}{|c|c|c|c|}
\hline Plant & Width & Thickness & Length \\
\hline 1 & $13.15^{\mathrm{ns}}$ & $13.21^{\mathrm{ns}}$ & $18.02^{\mathrm{ns}}$ \\
\hline 2 & $11.86^{*}$ & $11.84^{*}$ & $19.02^{*}$ \\
\hline 3 & $13.05^{\mathrm{ns}}$ & $13.02^{\mathrm{ns}}$ & $15.64^{\mathrm{ns}}$ \\
\hline 4 & $13.10^{\mathrm{ns}}$ & $13.16^{\mathrm{ns}}$ & $18.72^{\mathrm{ns}}$ \\
\hline 5 & $12.24^{\mathrm{ns}}$ & $12.25^{\mathrm{ns}}$ & $15.02^{\mathrm{ns}}$ \\
\hline 6 & $12.13^{*}$ & $12.16^{*}$ & $14.82^{*}$ \\
\hline 7 & $13.85^{\mathrm{ns}}$ & $13.80^{\mathrm{ns}}$ & $17.14^{\mathrm{ns}}$ \\
\hline 8 & $13.77^{\mathrm{ns}}$ & $13.77^{\mathrm{ns}}$ & $18.39^{\mathrm{ns}}$ \\
\hline 9 & $13.40^{\mathrm{ns}}$ & $13.43^{\mathrm{ns}}$ & $18.58^{\mathrm{ns}}$ \\
\hline 10 & $13.04^{\mathrm{ns}}$ & $13.24^{\mathrm{ns}}$ & $16.11^{\mathrm{ns}}$ \\
\hline 11 & $13.34^{\mathrm{ns}}$ & $13.33^{\mathrm{ns}}$ & $16.53^{\mathrm{ns}}$ \\
\hline 12 & $12.92^{\mathrm{ns}}$ & $12.91^{\mathrm{ns}}$ & $16.01^{\mathrm{ns}}$ \\
\hline 13 & $14.15^{\mathrm{ns}}$ & $14.19^{\mathrm{ns}}$ & $16.50^{\mathrm{ns}}$ \\
\hline 14 & $13.37^{\mathrm{ns}}$ & $13.39^{\mathrm{ns}}$ & $15.82^{\mathrm{ns}}$ \\
\hline 15 & $13.62^{\mathrm{ns}}$ & $13.50^{\mathrm{ns}}$ & $16.19^{\mathrm{ns}}$ \\
\hline 16 & $13.23^{\mathrm{ns}}$ & $13.20^{\mathrm{ns}}$ & $16.58^{\mathrm{ns}}$ \\
\hline 17 & $13.21^{\mathrm{ns}}$ & $13.35^{\mathrm{ns}}$ & $16.14^{\mathrm{ns}}$ \\
\hline 18 & $12.27^{\mathrm{ns}}$ & $12.39^{\mathrm{ns}}$ & $16.08^{\mathrm{ns}}$ \\
\hline 19 & $13.64^{\mathrm{ns}}$ & $14.00^{\mathrm{ns}}$ & $16.31^{\mathrm{ns}}$ \\
\hline 20 & $12.47^{\mathrm{ns}}$ & $12.68^{\mathrm{ns}}$ & $17.68^{\mathrm{ns}}$ \\
\hline 21 & $13.81^{\mathrm{ns}}$ & $13.91^{\mathrm{ns}}$ & $17.51^{\mathrm{ns}}$ \\
\hline 22 & $13.77^{\mathrm{ns}}$ & $13.92^{\mathrm{ns}}$ & $16.49^{\mathrm{ns}}$ \\
\hline 23 & $13.44^{\mathrm{ns}}$ & $13.48^{\mathrm{ns}}$ & $18.08^{\mathrm{ns}}$ \\
\hline 24 & $12.74^{\mathrm{ns}}$ & $12.80^{\mathrm{ns}}$ & $17.34^{\mathrm{ns}}$ \\
\hline 25 & $12.92^{\mathrm{ns}}$ & $12.95^{\mathrm{ns}}$ & $14.31^{*}$ \\
\hline 26 & $13.16^{\mathrm{ns}}$ & $13.13^{\mathrm{ns}}$ & $17.62^{\mathrm{ns}}$ \\
\hline 27 & $13.91^{\mathrm{ns}}$ & $13.89^{\mathrm{ns}}$ & $16.33^{\mathrm{ns}}$ \\
\hline 28 & $13.34^{\mathrm{ns}}$ & $13.21^{\mathrm{ns}}$ & $17.70^{\mathrm{ns}}$ \\
\hline 29 & $13.06^{\mathrm{ns}}$ & $13.03^{\mathrm{ns}}$ & $16.50^{\mathrm{ns}}$ \\
\hline 30 & $13.16^{\mathrm{ns}}$ & $13.22^{\mathrm{ns}}$ & $16.77^{\mathrm{ns}}$ \\
\hline 31 & $13.68^{\mathrm{ns}}$ & $13.68^{\mathrm{ns}}$ & $16.50^{\mathrm{ns}}$ \\
\hline 32 & $12.48^{\mathrm{ns}}$ & $12.46^{\mathrm{ns}}$ & $16.58^{\mathrm{ns}}$ \\
\hline 33 & $12.74^{\mathrm{ns}}$ & $12.86^{\mathrm{ns}}$ & $16.67^{\mathrm{ns}}$ \\
\hline 34 & $12.21^{\mathrm{ns}}$ & $12.32^{\mathrm{ns}}$ & $15.20^{\mathrm{ns}}$ \\
\hline 35 & $12.44^{\mathrm{ns}}$ & $12.46^{\mathrm{ns}}$ & $15.91^{\mathrm{ns}}$ \\
\hline 36 & $12.39^{\mathrm{ns}}$ & $12.86^{\mathrm{ns}}$ & $17.29^{\mathrm{ns}}$ \\
\hline Average & 13.08 & 13.14 & 16.73 \\
\hline
\end{tabular}

${ }^{\mathrm{ns}}$ not significant according to an $\mathrm{F}$ test; * significant according to an $\mathrm{F}$ test.

The morphometric characterization of seeds allows congeners to be differentiated (CRUZ; MARTINS; CARVALHO, 2001), and the dispersion form of the taxon and manner of seedling establishment to be identified (FENNER, 1993), as well as the tropical forest successional stage to which a species belongs (BASKIN; BASKIN, 1998). According to Moura et al. (2010), biometric differences in fruit and their seeds are related to environmental factors, and to how a population behaves during establishment in a new environment, in particular when a species is widely distributed. However, in the present study of individuals from different areas, no biometric differences were observed in $C$. prunifera seeds, indicating both homogeneity of the species in relation to the factors evaluated and uniformity of the evaluated characteristics in responding to environmental factors. Thus, the mixture of seeds obtained equally from different matrices provided a good estimate of the average behavior of the studied population. As the distribution of the species is much broader than 
used in the present study (ARRUDA; CALBO, 2004), it is possible that, if a larger number of plants were to be sampled in a larger number of regions, significant differences would be identified.

Based on the data analysis results, it was verified that there were no statistically significant differences in the evaluated variables when comparing groups of matrices using deviation analysis (Table 2). The coefficient of determination of order effects $\left(\mathrm{c}^{2}\right.$ proc $\left.\%\right)$ was used to determine the average percentage of difference between the groups; for most variables, this coefficient was below three. The reasons for there being no distinction between groups were probably related to similarities in the pressures on the three groups of individuals, as these were relatively close (Figure 1) to each other, with no significant difference in latitude and longitude. In addition, the three groups were situated in the same forest typology, characterized as caatinga. The environmental differences among indigenous populations of the groups of palms studied were not sufficient to promote genetic selection by favoring those genes that would promote genetic differentiation among populations. It is also possible that there has been gene exchange between the groups, thus preventing differentiation between the groups of matrices.

Table 2. Phenotypic mean of primary variables at different stages (height 30 days after emergence (A1); height 60 days after emergence (A2); height 90 days after emergence (A3); collection diameter 60 days after emergence (D1); collection diameter 90 days after emergence (D2); and survival) for three groups of spatially delimited Copernicia prunifera, and significance of the groups determined by deviance analysis.

\begin{tabular}{llllllllr}
\hline Variable & $\begin{array}{l}\text { Emergence } \\
(\%)\end{array}$ & IVE & A1 & A2 & A3 & D1 & D2 & Sob. \\
\hline Average G1 & 98.26 & 5.55 & 5.40 & 19.37 & 22.66 & 8.11 & 9.21 & 92.86 \\
Average G2 & 94.32 & 5.30 & 5.33 & 19.22 & 22.10 & 7.95 & 9.41 & 92.86 \\
Average G3 & 96.54 & 5.86 & 5.27 & 18.25 & 21.15 & 7.90 & 9.20 & 98.85 \\
\hline c $^{2}$ proc\% & 0.00 & 0.36 & 0.52 & 2.00 & 5.15 & 1.72 & 0.20 & 0.00 \\
\hline Sig. Proc. & $\mathrm{ns}$ & $\mathrm{ns}$ & $\mathrm{ns}$ & $\mathrm{ns}$ & $\mathrm{ns}$ & $\mathrm{ns}$ & $\mathrm{ns}$ & $\mathrm{ns}$ \\
\hline
\end{tabular}

Statistically significant at $99 \%$ of progression according to deviation analysis; ns, statistically not significant according to deviance analysis; IVE, emergence speed index; G1, group 1; G2, group 2; G3, group 3; $\mathrm{c}^{2}$ proc\%, coefficient of determination of provenance data; Sig. Proc., significance of procedure effects.

According to the results (Table 2), no genetic differences were observed among the evaluated populations in terms of the emergence, height, and diameter parameters of the $C$. prunifera seedlings. As there were no significant differences between progeny groups in the spatially delimited matrices, it is possible that seeds collected from the sampled matrices could be used for forest restoration throughout the sampling range, without affecting the gene pool of the species present in a given locality, based on evaluations carried out in the juvenile phase. However, the broad dispersion of the species indicates that a more comprehensive study is required, perhaps making use of molecular tools, because although the locations from which seeds were collected are very distinct from each other, they have similar climatic conditions. However, the species is distributed in different locations in other states, such as Bahia, Pernambuco, and Piauí. Thus, it is necessary to expand the study area in order to consolidate available information further. Future research should also cover the evaluation and further monitoring of individual trees in field experiments, in order to collect data of extreme relevance to the species. Such data gathering should include, for example, wax production from the leaves, which is probably a quantitative trait of low heritability and which is highly influenced by environmental conditions. In this context, the present work provided important information that needs to be complemented by other studies in order to better understand the genetic structure of the species, as well as to support the selection of genotypes with desirable commercial characteristics.

As the three groups of matrices did not differ genetically from each other, genetic parameters were estimated from all the matrices sampled (Table 3), with no reference to the groups. Based on the data analysis results, the experimental design and control were considered adequate, as they presented accuracy values of above $67 \%$ for almost all the evaluated characteristics (Table 3). According to Resende (2002), accuracy values from $70 \%$ indicate that estimated values are reliable when compared with actual values.

The most important function of heritability in biometric genetic study is to predict correspondence between the phenotypic and genetic value. This is a property not only of a character, but also of the population and environmental conditions to which individuals are subjected, and may be affected if there is a change in any of the components of genetic and phenotypic variances (FALCONER, 1981). For most of the characters evaluated in the present study, the coefficients of heritability (individual heritability in the narrow sense, additive heritability within plot, and heritability of the mean of progenies) can be considered medium to high (Table 3). These heritability coefficients indicated significant genetic control over the evaluated traits. A high magnitude 
of average heritability for the characteristic of height was observed, indicating that breeding programs could potentially benefit from the selection of superior genotypes, from among both progenies and individuals within progeny. Thus, it was possible to infer from the present study that juvenile morphological characters of $C$. prunifera can be used to evaluate genetic variability in populations sampled from the species. However, in view of the fact that the selection was undertaken at an early stage, an assessment of heritability in field conditions, and at more advanced stages of development, is indicated.

There are few papers that report heritability estimates relating to palm plants. Soh et al. (2003) report heritabilities varying from $22 \%$ to $36 \%$ for characters related to palm fruit production. In addition, a number of authors (CORLEY; HARDON; OOI, 1973) have reported average to high heritabilities $(21 \%$ to $65 \%)$ for growth characters. Farias Neto et al. (2007) report heritabilities for açaí palms varying from $12 \%$ to $44.63 \%$ for growth, height, and diameter characters. Farias Neto, Resende and Oliveira (2011) have found that the heritability coefficient estimated in the restricted sense for the fruit production character was of low magnitude $(0.1233)$ in açaí palm. Macaúba palm has been shown to have high coefficients of individual heritability in the restricted sense $(87 \%$ and $48 \%$ ), for plant growth and number of leaves produced by the plant, respectively (MANFIO et al., 2012). In coconut, growth traits present medium to high heritability (CARVALHO et al., 2008; YOKOMIZO; MELEM JUNIOR; FARIAS NETO, 2015). These values are consistent with and close to those obtained in the present study. All these estimates indicate favorable conditions for selection in palm plants. If a similar trend were to be observed for the genetic parameters in adult materials, then data from the present study could be considered in the early selection of $C$. prunifera.

Table 3. Estimation of genetic parameters for the primary variables (height 30 days after emergence (A1); height 60 days after emergence (A2); height 90 days after emergence (A3); collection diameter 60 days after emergence (D1); collection diameter 90 days after emergence (D2); and survival) of 40 progenies of Copernicia prunifera.

\begin{tabular}{lllllll}
\hline Variable & A1 & A2 & A3 & D1 & D2 & Sob. \\
\hline $\mathrm{h}^{2} \mathrm{a}$ & $0.709+-0.168$ & $0.329+-0.112$ & $0.525+-0.139$ & $0.924+-0.187$ & $0.004+-0.012$ & $0.135+-$ \\
& & & & & & 0.068 \\
$\mathrm{~h}^{2} \mathrm{mp}$ & 0.771 & 0.599 & 0.712 & 0.855 & 0.022 & 0.462 \\
Acprog & 0.878 & 0.774 & 0.844 & 0.925 & 0.149 & 0.679 \\
$\mathrm{~h}^{2} \mathrm{ad}$ & 0.759 & 0.307 & 0.523 & 0.967 & 0.003 & 0.106 \\
$\mathrm{CVgi} \%$ & 29.758 & 12.635 & 12.168 & 15.005 & 4.103 & 10.192 \\
$\mathrm{CVgp} \%$ & 14.879 & 6.318 & 6.084 & 7.503 & 2.051 & 5.096 \\
$\mathrm{CVe} \%$ & 18.121 & 11.545 & 8.655 & 6.895 & 30.461 & 12.302 \\
\hline $\mathrm{MG}$ & 5.339 & 18.958 & 21.971 & 8.005 & 9.271 & 0.928 \\
\hline Sig Gen & $* *$ & $* *$ & $* *$ & $* *$ & $\mathrm{~ns}$ & $* *$ \\
\hline
\end{tabular}

**statistically significant at $99 \%$ probability according to deviance analysis; ns, statistically not significant according to deviance analysis; $h^{2} a$, individual impairment in the narrow sense; $h^{2} m p$, loss of the average of progenies, assuming complete survival; Acprog, accuracy of progeny selection, assuming complete survival; CVgi\%, coefficient of genetic variation within families; $\mathrm{CVgp} \%$, coefficient of genetic variation among families; $\mathrm{Cve} \%$, coefficient of environmental variation; MG, character average; Sig Gen, statistical significance of genetic effects according to deviance analysis.

Estimates of the coefficient of genetic variation between and within progenies were observed to have an inside variance that was higher than the genetic variance among progenies for the characteristics evaluated (Table 3). The coefficient of genetic variation within families varied from 4.10 to $29.75 \%$, and that among families was between 2.051 and 14.88 (Table 3). The greater the genetic variation, the greater is the potential for genetic gain in breeding programs. The values determined in the present study revealed the possibility of using the material for breeding purposes, employing appropriate selection methods. Results showing genetic variation coefficients that are higher within than among families are usually found in progeny tests of allogamous forest species, according to work carried out for between one and two years by Ettori et al. (1996), involving 29 progeny tests of 13 tree species native to Brazil. Therefore, the results obtained in the present study for $C$. prunifera were in agreement with the values of genetic variation obtained from native tree species. However, these results should be compared to assessments of individuals at later stages of development in order to derive data for the juvenile genetic correlation $x$ adult, thus guaranteeing the reliability of early selection.

The use of progeny tests has been successfully used in several forest species, such as Paullinia cupana (ATROCH et al., 2010), Anacardium occidentale (PAIVA et al., 2007; SILVA et al., 2012), Hymenaea stigonocarpa (MORENO et al., 2009), Handroanthus avellanedae (SANTOS; CABRAL; COSTA, 2014), Jacaranda 
cuspidifolia (MORAES et al., 2013), Myracrodruon urundeuva (CARDERALLI et al., 2013), Cocos nucifera (FARIAS NETO et al., 2009), Caryocar brasiliense (GIORDANI et al., 2012) and Acrocomia aculeata (DOMICIANO et al., 2015).

The deviance analysis indicated that there were significant statistical differences for virtually all the variables, suggesting the existence of genetic differences between the progenies analyzed. It should be remembered that the evaluation of this work was undertaken at an early stage, in the seedling production phase, and that further monitoring at future developmental stages in the field is recommended. If such a pattern of genetic variation were to persist into adulthood, then the genetic material sampled could be considered to show good genetic variability, indicating its suitability for use in genetic improvement and forest restoration programs.

The Tocher method presents an average distance within groups that is always smaller than the average distance between groups (VASCONCELOS et al., 2007), so there will be more homogeneity between accessions of the same group than between those of different groups. Based on the dissimilarity expressed by the Mahalanobis genetic distance, the Tocher grouping method was used to determine the formation of three distinct groups, in which a concentration of progenies was observed in the first group (Table 4); the second group comprised progeny (genotype '40') that differed from other progeny due to a greater observed survival; and the third group comprised progeny (genotype ' 30 ') that differed from other progeny because the seedlings were taller.

Based on the genetic values of seedling height, diameter, and survival, dissimilarities between the progenies meant that $97.5 \%$ of the progenies were concentrated in a single group. This indicated that the progenies were morphologically very similar to the variables analyzed (height, diameter, and survival) in the seedling production phase; however, more advanced field experiment evaluations may diverge from these results, especially for other selection characters, such as leaf size, number of sheets, and wax content. However, should the results observed in the present study be confirmed in mature plants by the genetic correlation between juvenile and adult, then recombining the progenies between the different groups would be promising for seed production. This is because divergence between parents leads to greater variability in the segregating population, thus increasing the probability that the alleles responsible for characteristics of interest will be joined in new genetic combinations.

Table 4. Tocher method clustering of 40 genotypes of Copernicia prunifera, based on the dissimilarity expressed by the Mahalanobis genetic distance, estimated from eight characteristics.

\begin{tabular}{cc}
\hline Group & Genotype \\
\hline 1 & 12345678910111213141516171819202122 \\
2 & 24252627282931323334353739 \\
3 & 40 \\
\hline
\end{tabular}

\section{CONCLUSIONS}

The progenies showed no significant genetic differences when presented in spatially delimited matrices, and the juvenile characters of $C$. prunifera evaluated at the nursery stage showed good genetic control. If these trends are confirmed in the adult material based on the juvenile genetic correlation $x$ adult, then this would indicate that $C$. prunifera seeds collected from a greater number of individuals within populations than in our sample can be used for forest restoration, genetic conservation, and in potential breeding programs for this species in the region covered by this study.

\section{ACKNOWLEDGEMENTS}

The authors thank the National Council for Scientific and Technological Development (Conselho Nacional de Desenvolvimento Científico e Tecnológico - CNPq).

\section{REFERENCES}

ALVES, M. O.; COELHO, J. D. Tecnologia e relações de produção no extrativismo da carnaúba no nordeste brasileiro. In: XLIV CONGRESSO DA SOBER, 44., 2006, Fortaleza. Anais... Fortaleza: SOBER, 2006. p. 1-20.

ARRUDA, G. M. T.; CALBO, M. E. R. Efeitos da inundação no crescimento, trocas gasosas $\mathrm{e}$ porosidade radicular de carnaúba (Copernicia prunifera (Mill.) H. E. Moore). Acta Botanica Brasilica, São Paulo, v. 18, n. 2, p. 219-224, 2004.

ATROCH, A. L. et al. Avaliação e seleção de progênies de meios-irmãos de guaranazeiro. Revista de Ciências Agrárias, Belém, v. 53, n. 2, p. 123 130,2010

BASKIN, C. C.; BASKIN, J. M. Seeds: ecology, biogeography and evolution of dormancy and germination. Academic Press, San Diego, 1998. 200 
p.

BIERNASKI, F. A.; HIGA, A. R.; SILVA, L. D. Variabilidade genética para caracteres juvenis de progênies de Cedrela fissilis VELL.: subsídio para definição de zonas de coleta e uso de sementes. Revista Árvore, Viçosa, v. 36, n. 1, p. 49-58, 2012.

CARDERALLI, A. et al. Seleção precoce em progênies de meios irmãos de Myracrodruon urundeuva Fr. All. via metodologia reml/blup. Ambiência, Guarapuava, v. 9, n. 3, p. 605-617, 2013.

CARVALHO, E. X. et al. Variabilidade e comportamento de cultivares de coqueiro anão nos tabuleiros costeiros do norte de Sergipe. Bragantia, Campinas, v. 67, n. 1, p. 91-100, 2008.

CARVALHO, M. F. et al. Estudo de caso de três espécies de plantas bioindicadoras de solos salinos. Revista Verde, Pombal, v. 10, n. 3, p. 1-8, 2015

CORLEY, R. H. V.; HARDON, J. J.; OOI, S. C. Some evidence for genetically controlled variation in photosynthetic rate of oil palm seedlings. Euphytica, Wageningen, v. 22, n. 1, p. 48-55, 1973.

CRUZ, C. D.; FERREIRA, F. M.; PESSONI, L. A. Biometria aplicada ao estudo da diversidade genética. 1. ed. Visconde do Rio Branco, MG: Suprema, 2011.620 p.

CRUZ, E. D.; MARTINS, F. O.; CARVALHO, J. E. U. Biometria de frutos e sementes e germinação de jatobácuruba (Hymenaea intermedia Ducke, Leguminosae -Caesalpinioideae). Revista Brasileira de Botânica, São Paulo, v. 24, n. 2, p. 161-165, 2001.

DOMICIANO, G. P. et al. Parâmetros genéticos e diversidade em progênies de Macaúba com base em características morfológicas e fisiológicas. Ciência Rural, Santa Maria, v. 45, n. 9, p. 1599-1605, 2015.

ETTORI, L. C. et al. Variabilidade genética em populações de ipê-roxo - Tabebuia heptaphylla (Vell.) Tol. - para conservação ex situ. Revista do Instituto Florestal, São Paulo, v. 8, n. 1, p. 61-70, 1996.

FALCONER, D. D. Introdução a genética quantitativa. 1. ed. Viçosa, MG: UFV, 1981. 279 p.

FARIAS NETO, J. T. et al. Avaliação genética de progênies de polinização aberta de açaí (Euterpe oleracea) e estimativas de parâmetros genéticos. Cerne, Lavras, v. 13, n. 4, p. 376-383, 2007.

FARIAS NETO, J. T. et al. Seleção genética em progênies híbridas de coqueiro. Revista Brasileira de Fruticultura, Jaboticabal, v. 31, n. 1, p. 190-196, 2009.

FARIAS NETO, J. T.; RESENDE, M. D. V.; OLIVEIRA, M. S. P. de Seleção simultânea em progênies de açaizeiro irrigado para produção e peso do fruto. Revista Brasileira de Fruticultura Jaboticabal, v. 33, n. 2, p. 532-539, 2011.

FENNER, M. Seed Ecology. Chapman \& Hall, London, 1993. 340 p.

GIORDANI, S. C. O. et al. Parâmetros genéticos para caracteres de crescimento em pequizeiro em estádio precoce. Revista Ciência Agronômica, Fortaleza, v. 43, n. 1, p. 146-153, 2012.

HOLANDA, S. J. R. et al. Impacto da salinidade no desenvolvimento e crescimento de mudas de carnaúba (Copernicia prunifera (Miller) H. E. Moore). Revista Brasileira de Engenharia Agrícola Ambiental, Campina Grande, v. 15, n. 1, p. $47-52,2011$.

KAGEYAMA, P. Y. et al. Diversidade genética em espécies arbóreas tropicais de diferentes estágios sucessionais por marcadores genéticos. Scientia Florestalis, Piracicaba, v. 1, n. 64, p. 93-107, 2003.

MAGUIRE, J. D. Speed of germination aid in selection and evaluation for seedling emergence and vigor. Crop Science, Madison, v. 2, n. 2, p. 176-77, 1962

MANFIO, C. E. et al. Avaliação de progênies de macaúba na fase juvenil e estimativas de parâmetros genéticos e diversidade genética. Pesquisa Florestal Brasileira, Colombo, v. 32, n. 69, p. 63-68, 2012.

MORAES, M. A. et al. Variação genética em progênies de Jacaranda cuspidifolia Mart., utilizando o delineamento sistemático tipo "leque". Scientia Florestalis, Piracicaba, v. 41, n. 98, p. 175 183,2013

MORENO, M. A. et al. Estrutura genética espacial em populações de Hymenaea stigonacarpa Mart. ex Hayne mediante a utilização de marcadores microssatélites. Scientia Forestalis, Piracicaba, v. 37, n. 84, p. 513-523, 2009.

MOURA, R. C. et al. Biometria de frutos e sementes de Butia capitata (Mart.) Beccari (Arecaceae), em vegetação natural no Norte de Minas Gerais, Brasil. Biota Neotropica, Campinas, v. 10, n. 2, p. 415-419, 2010 .

OLIVEIRA, A. B.; BOSCO, M. R. O. Biometria, determinação da curva de absorção de água em 
sementes e emergência inicial de plântulas de Copernicia hospita Martius. Revista Brasileira de Agroecologia, Pelotas, v. 8, n. 1, p. 66-74, 2013.

PAIVA, J. R. et al. Seleção de clones de cajueiro comum pelo método em tandem e índice de classificação. Ciência e Agrotecnologia, Lavras, v. 31, n. 3, p. 765-772, 2007.

REIS, R. G. E. et al. Biometria e efeito da temperatura e tamanho das sementes na protrusão do pecíolo cotiledonar de carnaúba. Revista Ciência Agronômica, Fortaleza, v. 41, n. 1, p. 81-86, 2010.

REIS, R. G. E. et al. Emergência e qualidade de mudas de Copernicia prunifera em função da embebição das sementes e sombreamento. Revista Caatinga, Mossoró, v. 24, n. 4, p. 43-49, 2011.

RESENDE, M. D. V. Genética biométrica e estatística no melhoramento de plantas perenes. 1 . ed. Brasília, DF: Embrapa Informação Tecnológica, 2002. 975 p.

RESENDE, M. D. V. O Software Selegen- Reml/ Blup. 1. ed. Brasília, DF: Empresa Brasileira de Pesquisa Agropecuária, 2006. 67 p.

SANTOS, L. S.; CABRAL, G. P.; COSTA, R. R. G. F. Variabilidade genética entre e dentro de progênies de ipê rosa (Handroanthus avellanedae (Lorentz ex Griseb.) Mattos (Bignoniaceae). Global Science Technology, Rio Verde, v. 7, n. 2, p. 98-105, 2014.

SEBBENN, A. M. Sistemas de reprodução em espécies tropicais e suas implicações para a seleção de árvores matrizes para reflorestamentos ambientais. In: HIGA, A. R.; SILVA, L. D. (Eds.). Pomar de sementes de espécies florestais nativas. Curitiba: FUPEF do Paraná, 2006. v. 1, cap. 5, p. 93 138.

SILVA, S. S. et al. Estimativas de parâmetros genéticos e predição de valores genotípicos no melhoramento do cajueiro anão precoce pelo procedimento de REML/BLUP. Enciclopédia Biosfera, Goiânia, v. 8, n. 15, p. 867-881, 2012.

SOH, A. C. et al. Oil palm genetic improvement. Plant Breeding Reviews, West Lafayette, v. 22, n. 1, p. 165-219, 2003.

VASCONCELOS, E. S. et al. Estratégias de amostragem e estabelecimento de coleções nucleares. Pesquisa Agropecuária Brasileira, Brasília, v. 42, n. 4, p. 507-514, 2007.

VENCOVSKY, R.; BARRIGA, P. Genética biométrica no fitomelhoramento. Ribeirão Preto,
SP: Sociedade Brasileira de Genética, 1992. 496 p.

VIEIRA, R. I.; OLIVEIRA, J. S.; LOIOLA, M. I. B. Efeitos do extrativismo de fibras de carnaúba, Piauí, Brasil. REDE, Fortaleza, v. 10, n. 1, p. 96-109, 2016

YOKOMIZO, G. K.; MELÉM JÚNIOR, N. J.; FARIAS NETO, J. T. Desempenho de progênies de coqueiros no Amapá com base em caracteres vegetativos. Revista Ciências Agrárias, Belém, v. 58, n. 4, p. 335-341, 2015. 